\title{
Cuticulear hydrocarbons profiles of seven common Egyptian mantis
}

\author{
Salwa K. Mohammad, Sohair M .Gad Alla, Hayam El-Hamouly and \\ Mohammad G. El-Den Nasser. \\ Department of Entomology, Faculty of Sciences, Ain Shams Univ., Cairo, Egypt.
}

\begin{abstract}
This is the first chemical taxonomic study of cuticular hydrocarbons of seven common mantis species in Egypt. This study is shedding the light on the role of this chemicals in phylogeny and taxonomy of this charismatic group of Insects.
\end{abstract}

Key words: cuticuler hydrocarbons, cuticuler extractions, Empusidae, Eremiaphilidae, Mantidae, Tarachodidae, phylogeny.

\section{INTRODUCTION}

The cuticular hydrocarbon and lipids of most insect orders have been investigated to some extent and have served as taxonomic characters since the eighties of the last century (Castner \& Nation 1984 \& Carlson 1988). Along with their primary role in controlling dehydration, components of these mixtures have been found to act as pheromones and do many other functions in most insect species (Steinmetz et. al 2003 \& Rolph et. al 2005).

As a part of an ongoing study of the taxonomy and ecology of mantis in Egypt (Kamal et. al 2010) the cuticular extracts of seven species commonly found in Egypt were investigated. This study forms the first step in studying cuticular hydrocarbons of old world mantis and using the output data for phylogenatic analysis by except the work on most common USA mantis species in the end of last century (Jonesa et al. 1997).

\section{MATERIALS AND METHODS}

Seven species belong to the four Egyptian families of order Mantodea and represent most common mantis species in Egypt, were used in this study. The specimens were collected from the field by hand picking and killed using ethyl acetate that consider as a solvent and doesn't affect the result.

The seven species, Blepharopsis mendica Fabricius (Hc6), Empusa guttula Thunberg (Hc3), Eremiaphila rufipennis Uvarov (Hc1), Iris oratoria Linnaeus (Hc2), Mantis religiosa Linnaeus (HC4), Miomantis paykullii Stål (Hc5) and Sphodromantis viridis Forskal (Hc7), were identified using several keys and species descriptions (Saussure 1971; Innes 1911 \& 1912; Giglio-Tos 1927; Ibrahim 1979; Kaltenbach 1982).

Each female specimen was socked in methylene chloride for about two days for extraction of hydrocarbons found in the mantis cuticle. The concentrated extracts were analyzed by gas chromatography technique (GC). The data were obtained using Dani 1000 Italian GC equipped with $105 \mathrm{~m} \times 0.25 \mathrm{~mm} \quad \mathrm{ID} \times 0.5 \mu \mathrm{mdf} \quad 100 \%$ dimethylpolysiloxane column. The oven was programmed to run from 60 to $100^{\circ} \mathrm{C}$ at $15^{\circ} \mathrm{C} / \mathrm{min}$ and from 100 to $310^{\circ} \mathrm{C}$ at the rate of $15^{\circ} \mathrm{C} / \mathrm{min}$. the injection temperature 
was $250^{\circ} \mathrm{C}$ using helium $(\mathrm{He})$ as a carrying gas with flow rate $2 \mathrm{ml} / \mathrm{min}$ splitlen injection. The detection occurred by FID detector at $320^{\circ} \mathrm{C}$.

The output chromatograms were analyzed and each peak got a symbol from a - u. The peaks with the same retention time in the different species take the same symbol. The presence/absence data obtained were analyzed using probiosys software to create phelograms of the seven species.

\section{RESULT AND DISCUSSION}

The results indicated that the cuticular extractions of the seven species contain twenty one kinds of hydrocarbons. The lighter hydrocarbon emitted at retention time 15.6 minutes and the heavier one emitted at retention time 34.9 minutes; $19.04 \%$ of the detected hydrocarbons are specific to single species, $4.76 \%$ are found in all species under investigation and $76.19 \%$ are shared between them. The cuticular extractions of Sphodromantis viridis Forskal (Hc7) has the large number of hydrocarbons with 12 types while the extractions of Empusa guttula Thunberg (Hc3) has the lowest number with only 9 types (Table 1).

Table 1: The distribution of hydrocarbons peaks among mantis species

\begin{tabular}{|c|c|c|c|c|c|c|c|c|c|c|c|c|c|c|c|c|c|c|c|c|c|}
\hline & 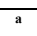 & b & $\bar{c}$ & $\mathrm{~d}$ & e & $\mathrm{f}$ & $\mathrm{g}$ & $\mathrm{h}$ & $\mathrm{i}$ & $j$ & $\mathbf{k}$ & 1 & $\mathrm{~m}$ & $\mathrm{n}$ & 0 & $p$ & $q$ & $\mathrm{r}$ & $\mathrm{s}$ & $t$ & $\mathrm{u}$ \\
\hline Ret. & 15.6 & 18.0 & 18.7 & 20.7 & 21.5 & 22.7 & 23.8 & 24.2 & 24.9 & 25.8 & 26.7 & 27.7 & 28.1 & 28.5 & 29.3 & 29,7 & 30.1 & 31.1 & 32.6 & 33.4 & 34.6 \\
\hline $\begin{array}{c}\text { Time } \\
\text { (m) }\end{array}$ & 15.9 & 18.3 & 19.0 & 21.0 & 21.8 & 23.0 & 24.1 & 24.5 & 25.2 & 26.1 & 27.0 & 28.0 & 28.4 & 28.8 & 29.6 & 30.0 & 30.4 & 31.4 & 32.9 & 33.7 & 34.9 \\
\hline Hel & + & & + & & + & + & + & & & + & & + & & + & + & & & + & + & & \\
\hline HC2 & + & & + & & + & + & + & + & & + & & + & & & + & & & + & + & & \\
\hline $\mathrm{HC} 3$ & & & & + & & + & & + & + & & + & & + & & & + & & + & + & & \\
\hline Hc4 & + & & + & & $t$ & + & + & & & \pm & & $t$ & & & + & & + & + & & + & \\
\hline & & & & & & & & & & & & & & & & & & & & & \\
\hline Hes & + & & + & & + & & + & + & & + & & + & & & + & & & + & + & & \\
\hline Hс6 & + & & & + & & + & & + & + & & + & & + & & & + & + & + & + & & \\
\hline Hc7 & & + & + & & + & + & + & + & & + & & + & & & + & & & + & + & & + \\
\hline
\end{tabular}

The seven chosen species are classified according to Ehrmann 2002, Otte \& Spearman 2005 and molecular phylogenatic study of Gavin \& Michae 2009; Blepharopsis mendica Fabricius (Hc6), Empusa guttula Thunberg (Hc3) belong to family Empusidae, Eremiaphila rufipennis Uvarov ( $\mathrm{Hc1}$ ) belong to family Eremiaphilidae, Iris oratoria L. (Hc2) belong to family Tarachodidae, Mantis religiosa L. (HC4), Miomantis paykullii Stål (Hc5) and Sphodromantis viridis Forskal (Hc7) belong to family Mantidae.

The phelogenatic analysis based on the presence and abscence of cuticuler hydrocarbon types in the seven species (fig $1 \&$ Table 2) divided them into two main clusters: the first one containing ( $\mathrm{Hc} 1, \mathrm{Hc} 2, \mathrm{Hc} 4, \mathrm{Hc} 5$ and $\mathrm{Hc} 7)$ and the second cluster containing (Hc3 and Hc6). The first cluster shared between three families Eremiaphilidae, Mantidae and Tarachodidae. The second cluster contains species of family Empusidae.

Table 2: The resemblances index between the seven species

\begin{tabular}{|l|l|l|l|l|l|l|l|}
\hline & Hc1 & Hc2 & Hc3 & Hc4 & Hc5 & Hc6 & Hc7 \\
\hline Hc1 & 100.000 & & & & & & \\
\hline Hc2 & 90.476 & 100.000 & & & & & \\
\hline Hc3 & 33.333 & 42.857 & 100.000 & & & & \\
\hline Hc4 & 80.952 & 80.952 & 23.810 & 100.000 & & & \\
\hline Hc5 & 85.714 & 95.238 & 38.095 & 76.190 & 100.000 & & \\
\hline Hc6 & 33.333 & 42.857 & 90.476 & 33.333 & 38.095 & 100.000 & \\
\hline Hc7 & 76.190 & 85.714 & 38.095 & 66.667 & 80.952 & 28.571 & 100.000 \\
\hline
\end{tabular}




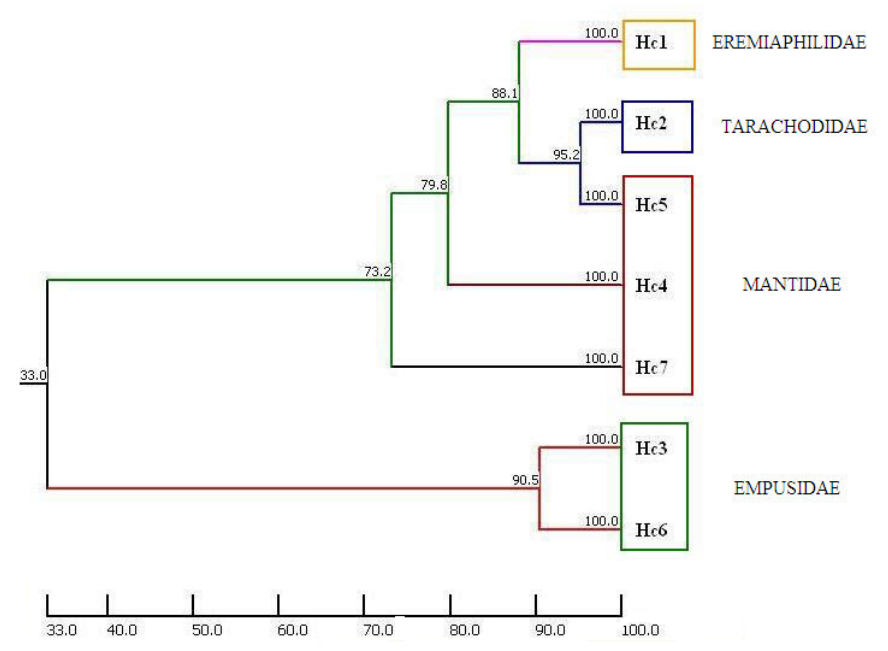

Fig. 1: Showing the phylogram based on presence /absence data of cuticular extractions of the seven mantis species.

The main issues to be discussed about the phylogram induced using data of cuticulear hydrocarbons are the clear difference between cuticuler extractions of the family Empusidae and the three other families, which reflect the great difference in their morphology; the position of species of family Mantidae in the first cluster reflect their new taxonomic position according to the classification and phylogenatic analysis of Gavin \& Michae 2009 as Mantis religiosa L. (HC4) and Sphodromantis viridis Forskal (Hc7) belongs to subfamily Paramantinae and two differant tribes M.religiosa (Mantini) and S.viridis (Paramantini), while Miomantis paykullii Stål (Hc5) belongs to subfamily Miomantinae; approval of the taxonomic status of Iris oratoria Linne (Hc2) is now at stake as its position is more related to family Mantidae than to family Tarachodidae which genus Iris transfer to it in classification of Ehrmann 2002, Otte \& Spearman 2005 and Gavin \& Michae 2009; the difference between genera within family Empusidae and Mantidae can't be clear in our qualitative study but the absence and presence of some types of hydrocarbons between these genera may give an idea about such differance which will appear in more deep qualitative study.

\section{ACKNOWLEDGMENT}

We greatly thank Dr. Hitham B. Mosa from Ain Shams University for his support on analyzing the out put data and also we need to thank Reinhard Ehrmann from the Staatliches Museum für Naturkunde for providing important literatures and Dr. Francis Gilbert from School of Biology, Nottingham University, UK for his comments.

\section{REFERENCES}

Carlson, D.A. (1988). Hydrocarbons for identification and phonetic comparisons: cockroach, Honey bees and Tsetse flies-The Florida Entomol., 71(3):333345.

Castner, J.L. and Nation, J.L. (1984). Cuticular lipids for species recognition of mole crickets (Orthoptera:Gryllotalpidae)-The Florida Entomol., 67(1): 155-160.

Ehrmann, R. (2002). Mantodea - Gottesanberinnen der Welt. - Natur und Tier-Verlag, 519 S., 13 table, 56 Grafic, 194 fig.; Münster. 
Gavin, J. S. and Michael, F. W. (2009). Reconstructing the origins of praying mantises (Dictyoptera, Mantodea): the roles of Gondwanan vicariance and morphological convergence.-Cladistics, 25:1- 47.

Giglio-Tos, E. (1927). Das Tierreich. Orthoptera-Mantidae.-Walter de Gruyter \& Co., 50. edit., 707 S., 25 fig.; Berlin.

Ibrahim, S. (1979). Mantodea of Egypt-Msc. Faculty of Science Thesis, Ain Shams Univ.,

Innes, W. (1911). Une liste d'insectes recueillis probablement par J. Lord, en Égypte et déterminés par F. Walker. - Bull. Soc. Entom. Égypte, 40: 97-115.

Innes, W. (1912). Revision des Orthoptères de l'Égypte. 3. Famille Mantides. - Mém. Soc. Entomol. Égypte, 1(3): 3-6, 39-78, pl. 1-4; Kairo.

Jonesa, T. H.; Moranb, M. D. and Hurd, L.E (1997). Cuticular extracts of five common mantids (Mantodea:Mantidae) of the eastern United States-Comp Biochem. Physiol Biochem Mol Biol.; 116(4):419-22.

Kaltenbach, A. P. (1982). Insects of Saudi Arabia. Mantodea.- Fauna of Saudi Arabia, 4: 29-72, 118 fig.; Basel.

Kamal, S. M.; Gad Alla, S. M.; El-Hamouly, H. and Nasser, M. G. (2010 under publication). Taxonomic Revision and Cuticulear Hydrocarbon Profile of order Mantodea in Egypt - MSc. Thesis, Ain Shams University.

Otte, D. and Spearman, L. (2005). Mantida - species file. Catalog of the mantids of the world.-Insect Diversity Association Publication, 1:1-489; LouisvilleUSA.

Ralph W. Howard, and Gary J. Blomquist (2005). Ecological, Behavioral, and Biochemical Aspects of Insect Hydrocarbons-Annual Review of Entomology, 50: 371-393.

Saussure, H. (1871). Mélanges Orthoptérologiques - IV. Mantides. - Mém. Soc. Physique, 3. Lfg., 21(2): 1-214, Taf. 4- 6.

Saussure, H. (1871). Mélanges Orthoptérologiques - Mantides. - Mém. Soc. Genève, Suppl., 3. Lfg., 21(2): 239-337, Taf. 7; Genf.

Saussure, H. (1871). Mélanges Orthoptérologiques - IV. Mantides. - Genève \& Bâle, H. Georg, 1863-1871, 3. Lfg., 1(2): 149-362, Taf. 4-6., (Nachdruck von: Mem. Soc. Physique, 3. Lfg., 21(2): 1-214, Taf. 4-6, 1871); Genf.

Saussure, H. (1871). Mélanges Orthoptérologiques - Mantides. - Genève \& Bâle, H. Georg, 1863-1871, Suppl., 3. Lfg., 21: 363-462, Taf. 7, (Nachdruck von: Mem. Soc. Physique, Suppl., 3. Lfg., 21(2): 239-337, Taf. 7, 1871); Genf.

Steinmetz, I.; Schmolz, E. and Ruther, J. (2003). Cuticular Lipids as Trail Pheromone in a social Wasp - Biological Sciences, 270 (1513): 385-391.

\section{ARABIC SUMMARY}

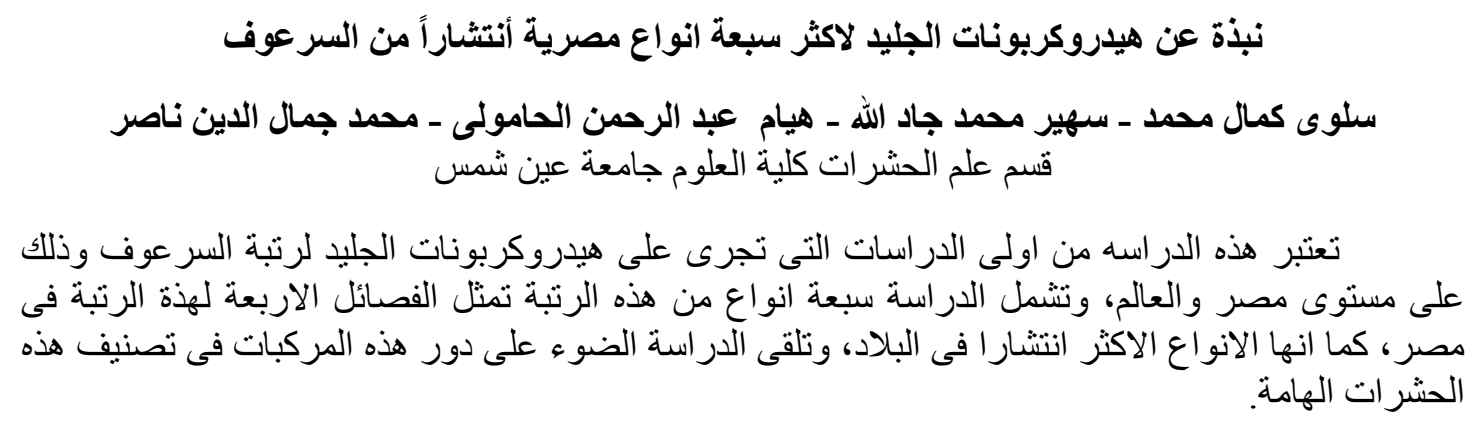

